\title{
The Spanish Path of Agrarian Change, 1950-2005: From Authoritarian to Export- Oriented Productivism
}

\begin{abstract}
The aim of this study is to determine whether the evolution of Spain's agrarian change, between 1950 and 2005, exhibits any features important enough to differentiate it from the common model of developed countries in Western Europe. On the one hand, the Spanish agrarian transformations share the main features of the changes in Western Europe: technological innovation, increased production and productivity, diminishing importance of the agricultural sector, close integration with the industrial sector and a high environmental impact. On the other hand, a series of important peculiarities can be observed in Spain's agrarian change: strong expansion of intensive livestock farming; the role of increased irrigation in explaining the transformation of agriculture; policies that offered very little support to the agricultural sector under a dictatorship that denied a voice to farmers; the prominent role of agriculture in the economy despite its small contribution to GDP.
\end{abstract}

Keywords: Agrarian change, Agricultural policies, European agriculture, European economic history, Spanish agriculture

\section{INTRODUCTION}

The agricultural sector was the largest employer in pre-industrial Europe and the principal contributor to the GDP of its economies. Today, however, in these same countries the agricultural sector has very little economic weight as a result of the industrialisation processes that took place from the end of the eighteenth century. There is an extensive body of historic and economic literature analysing the characteristics and consequences of the transformation of a traditional agricultural system into a modern one. This analysis is highly interesting as important lessons can be drawn for developing countries in which these transformation processes have not yet concluded or are in an early stage. The transition from a rural society to an urban society, or the 
transformation of an unproductive but energetically efficient agricultural sector which is harmless to the environment into one capable of producing many more foods, but which is not energy efficient and is highly contaminating to the environment, is a crucial historical process.

The agricultural sector has experienced significant transformations over the last three centuries, particularly during the last hundred and fifty years. However, the changes that have taken place fade in comparison with the intensity of the occurrences after 1950. The comparison made by Bairoch (1999) between the "three agricultural revolutions" clearly shows the strong growth of productivity in the second half of the twentieth century with respect to any previous period. Therefore, we can conclude that the extent of the transformations in the agricultural sectors of developed countries (and even in those of many developing countries) after 1950 certainly deserves to be described as a "revolution". Authors such as Grigg (1992), Federico (2005), Malassis (1997) and Hamilton (2014) identify this period as when the great transformation of western agriculture took place, with the definitive change from a traditional agriculture to a modern agriculture, or from an extensive agriculture with growth based on an increase in the use of inputs to an intensive one in which the increases in productivity constituted the principal dynamic element. Ultimately, agriculture shifted towards a new model, the "internationalised agribusiness model", based on the industrialisation of the agri-food chain with an increasing replacement of traditional products with processed and prepared products within an agricultural environment that was becoming more and more dependent on price systems and international exchanges. In this model, the global 
agricultural sector became dominated first by the agribusiness and then by mass distribution ${ }^{1}$.

Furthermore, the manner in which the institutions, particularly the State, interacted with the agricultural sector also changed. The policies implemented in developed countries after 1945 gave rise to a consolidation of a model of agricultural protection and intervention at the expense of consumers (Brassley et al. 2012) ${ }^{2}$. A clear example of this turnaround in agricultural policy was the implementation of the Common Agricultural Policy in Europe (hereafter, CAP) in 1962.

In general terms, the different developed countries experienced these transformation processes in a fairly similar way, sharing a series of common features, giving rise to a common pattern of change. However, there were also significant differences residing in the different institutional, political, social and economic contexts of each country.

Within this framework, the objective of this article is to determine the features of the model of agrarian change in Spain after 1950, going beyond those aspects shared with other developed countries, particularly those of Western Europe. The Spanish case is particularly interesting for three reasons. First, between 1950 and 1975, Spain was the only western European country (together with Portugal) to experience a significant agrarian transformation in a non-democratic political context. In other words, the Spanish agricultural policies were designed within a political dictatorship. Furthermore, and as a consequence of this, Spain did not participate in any of the important European

\footnotetext{
${ }^{1}$ This new model prompted John H. Davis to coin the term agribusiness in 1955, which defined a new type of agriculture that was "inseparable from the business firms which manufacture production supplies and which market farm products" (Davis 1955).

${ }^{2}$ Although Federico (2012) pinpoints 1933 as the true point of inflection in agrarian policies with the approval in the United States of the Agricultural Adjustment Act (AAA) by Roosevelt's government in order to combat the depression. Furthermore, the intense interventionism and the strict regulations during the Second World War were also crucial.
} 
regional trade agreements (RTAs) until 1986 when it became a member of the Economic European Community. Therefore, Spain carried out its profound agricultural transformation within a context of a much greater economic isolation than the rest of the developed countries, as it was clearly autarchic until 1959 after which there was a slight and very gradual liberalisation until 1986. Finally, Spain, together with Portugal and Italy, had the lowest levels of economic development in Western Europe in 1950. In the following decades, these three countries experienced intense growth processes, although at different paces.

After this introduction, the article is structured into two main parts. In the first part we will briefly describe the main common features of the modernisation of agriculture in the Western European countries after the Second World War, and the extent to which Spain shared these features. In the second part we will focus on identifying the peculiarities and distinctive characteristics of the Spanish model that differentiate it from the standard western model. The paper ends with some conclusions.

\section{THE AGRARIAN TRANSFORMATION OF THE WESTERN EUROPEAN}

\section{COUNTRIES AND SPAIN}

After the Second World War, agriculture in developed countries underwent a profound transformation with significant technological innovations, continuing a process that had begun before the outbreak of the conflict. Therefore, the process comprised the improvement and dissemination of some of the technological innovations introduced in previous decades such as the hybridisation of seeds or self-propelled agricultural machinery. Consequently, agricultural production and productivity increased substantially (Federico 2005; Grigg 1992; Martín-Retortillo and Pinilla 2015a, 2015b; Olmstead and Rhode 2008). These transformations took place within a 
context of intense structural change in the economies of these nations, which drained an enormous volume of the active population away from agriculture and towards industry and services. The following section summarises the main common characteristics of the process of agrarian change in developed countries from 1950 and examines the extent to which they also characterised the growth of the Spanish agricultural sector.

\section{Technological Innovation}

The speed of technological innovation increased considerably during the decades after 1945. The principal innovations adopted were intensive fertilisation, the use of pesticides, the spread of self-propelled machinery and the use of high-yield seeds.

The mechanisation of farming in Spain developed very quickly, taking into account that even as late as 1947 almost 90 per cent of all traction used in Spanish agriculture depended on muscular power. Only twenty-five years later, 95 per cent of all of this energy was provided by mechanical traction. The evolution of the number of tractors per hectare reveals that the introduction of machinery was even more intense in Spain than in the rest of Western Europe. In the same way as in the EU-9 $9^{3}$ (European Union), the most intense growth occurred in the period 1950-1985, although in Spain the growth rate was almost double that of the rest of the continent and the EU-9. This trend of greater growth continued after 1985, like in the other three European Mediterranean countries (O.E.M.C.), while in Europe the increase was less pronounced and in the EU9 it even decreased.

\footnotetext{
${ }^{3}$ UE-9 includes the figures for Germany, Belgium-Luxembourg, Denmark, France, Netherlands, Ireland, Italy and The United Kingdom.
} 
Table 1. Annual growth rates of tractors per thousand hectares (percentage)

\begin{tabular}{crr}
\hline & $1950-85$ & \multicolumn{1}{c}{$1985-2005$} \\
\hline Spain & 10.99 & 2.93 \\
\hline Europe & 7.05 & 0.54 \\
\hline EU-9 & 6.36 & -0.43 \\
\hline O.E.M.C. & 10.02 & 3.03 \\
\hline
\end{tabular}

Calculation based on triennial averages of 1950, 1985 and 2005.

EU-9 includes Belgium-Luxembourg, Netherlands, France, UK, Ireland, Italy, Denmark, and, between 1950 and 1985, we have included the German Federal Republic. Between 1985 and 2005, we have taken into account the reunified Germany.

Europe includes 31 European countries, based on the sample of Martín-Retortillo and Pinilla (2015b) and excludes Albania.

O.E.M.C. $=$ Other European Mediterranean Countries include Greece, Italy and Portugal.

Source: Own calculation based on FAOSTAT (2009) and FAO (1948-2004)

The initial low level of mechanisation explains this increased growth rate in the early years of the period studied, which explains the convergence process of Spanish agriculture towards the higher level of mechanisation in Europe ${ }^{4}$. The number of tractors in absolute terms confirms not only that Spain followed the European trend but also that it converged with the European level ${ }^{5}$.

The use of fertilizers also increased considerably. In the 1950s, the growth rate was particularly fast because Spain was recovering from the backward steps taken in fertilizer use during the 1940s due to the autarchic policy of the Franco regime and the difficulties in importing fertilizers during the Second World War and the early post-war years.

Table 2. Annual growth rates in the use of fertilizers (Tonnes of nutrients/ Ha), 1950-

$$
2005 \text { (percentage) }
$$

\footnotetext{
${ }^{4}$ Part of the subsequent reduction in the growth rate can be explained by the increase in the power of the tractors occurring during the second half of the twentieth century.

${ }^{5}$ The comparison with France is particularly significant. In 1950, the number of tractors in France was eight and a half times more than those in Spain. In 1985, the French tractors were less than two and a half times the number in Spain. In 2005, the French figure was only 1.2 times more than the Spanish figure.
} 


\begin{tabular}{lrrr}
\hline & $1950-60$ & $1960-85$ & $1985-2005$ \\
\hline Spain & 8.98 & 3.69 & 1.84 \\
\hline Europe & 6.45 & 3.94 & -2.16 \\
\hline EU-9 & 5.75 & 3.25 & -2.35 \\
\hline O.E.M.C. & 6.99 & 4.67 & -1.22 \\
\hline
\end{tabular}

Source: Own calculation based on IFA (2014), FAOSTAT (2009) and FAO (1948-2004)

However, in absolute terms, the increasing use of chemical fertilisation in Spain was due to much more than a simple catching-up process. In fact the total tonnes used increased from less than half of the EU-9 average in 1950 to almost the same amount in 1975 and above the EU-9 average in 1995.

\section{An Increase in Capital Stock and a Reduction in the Use of Traditional Inputs}

The adoption of new technologies implied a reduction in the use of traditional factors of production, land and labour and a significant increase in the weight of the capital factor. In Europe, the use of capital increased until the mid 1980s, after which it stagnated or even declined, coinciding with a slowdown in agricultural production. Spain was no exception in this process of incorporating capital into its agricultural sector. Between 1950 and 2005, in Spain the use of capital increased at an annual average rate of 3.6 per cent, which was significantly higher than that of the other countries in Western Europe. Furthermore, the use of capital continued to grow after 1985, when this growth was negative in the vast majority of the other European countries.

At the same time, in the Spanish agricultural sector the use of labour decreased (at an annual rate of 2.5 per cent) as did the use of land (at an annual rate of 0.2 per cent) (Martín-Retortillo and Pinilla 2015a, 151-3). The rural exodus experienced in Spain during the second half of the twentieth century matched the overall European trend, 
though the number of agricultural workers did not decrease significantly until the beginning of the 1960s (Collantes and Pinilla 2011), while in the Western European countries this decrease occurred decades beforehand (Grigg 1992). Finally, the fall in the number of agricultural workers in absolute terms was 75 per cent, which was slightly lower than that of other Western European countries (81 per cent).

In the case of the use of land, Spain diverged from the European trend during the first decades of the post-war period. In Spain, the use of land continued to grow until 1970 by which time in Western Europe, the volume of cultivated land had decreased (Clar 2013). However, from this year it also decreased in Spain. For the whole of the period 1950-2005, the absolute reduction in the use of land was similar to that of the countries close to Spain, such as Great Britain or France (Martín-Retortillo and Pinilla 2015a, 140).

Table 3. Annual growth rates of agricultural labour population, 1950-2005 (percentage)

\begin{tabular}{lrc}
\hline & $1950-85$ & $1985-2005$ \\
\hline Spain & -2.20 & -3.08 \\
\hline Europe & -2.49 & -3.45 \\
\hline EU-9 & -3.63 & -3.40 \\
\hline O.E.M.C. & -2.61 & -3.27 \\
\hline
\end{tabular}

Source: Own calculation based on FAOSTAT (2009) and FAO (1948-2004)

\section{The Search for Economies of Scale}

When millions of people abandoned farming there was also a strong reduction in the number of farms. The land was concentrated into the remaining farms, increasing their average size. The small farms were most affected by this process and therefore account for a high percentage of those that disappeared. On the other hand, the number of large agricultural holdings grew (Fennell 1997, 74). The Spanish case is a perfect example of 
this trend. So, for example, in Spain between 1962 and 1982, of the more than 400,000 agricultural holdings that disappeared, 72.5 per cent of them were farms with less than 5 hectares, while those with between 50 and 100 hectares or more than 100 hectares continued to grow between these two dates. The result was an increase in the average size of the Spanish farm of 35 per cent (Genovés 1994, 176). This process was reinforced by Spain's accession to the EU (Extezarreta 2006, 277). This trend widened the difference in size between Spanish agricultural holdings and those of the other three Mediterranean countries where the average size of the farms was much smaller (Table 4).

Table 4. Evolution of the average size of agricultural holdings (has), 1990-2005

\begin{tabular}{lrrr}
\hline & 1990 & 2000 & 2005 \\
\hline Spain & 12.2 & 18.6 & 23.0 \\
EU-9 & 18.8 & 20.5 & 24.7 \\
O.E.M.C. & 4.7 & 5.6 & 6.4 \\
\hline
\end{tabular}

Source: Own elaboration based on EUROSTAT (2013), Arable land. For EU-9, the data for France in 1990 and 2000 correspond to its Agricultural Censuses of 1988 and 2000 (Agreste, 2012).

\section{Rapid Growth of Productivity}

A fundamental feature of the agrarian change process in Western European countries in the second half of the twentieth century was a very rapid increase in the productivity levels that far exceeded those of a century and a half before (Bairoch 1999; Federico 2005). Both the productivity of the land and of labour or total factor productivity increased strongly. So, for example, between 1950 and 2005, labour productivity grew in western European countries at an annual average rate of 4.5 per cent, in Nordic countries at 3.5 per cent and in Mediterranean European countries at 4.4 per cent. Labour productivity grew in Spain during the same period at an annual average 
rate of 4.9 per cent (Martín-Retortillo and Pinilla 2015b). The strong growth in production, at least until approximately 1990, was achieved thanks to the intense use of capital and particularly to the afore-mentioned technological innovations. This, together with the exodus of millions of workers from the farming sector, explains the improvement in labour productivity.

This decrease in the agricultural workforce in Europe during the second half of the twentieth century was caused by a rural exodus, with intense flows from agricultural to non-agricultural sectors of the economy. Mediterranean countries were no exception in this process of structural change. In these countries, not only was there a large exodus from the rural areas to the towns, but large volumes of the rural population also moved towards other European countries with higher income levels, such as Germany, France, Belgium or the Netherlands. The fall in the number of agricultural workers largely explains the increase in productivity, beyond the impact of output levels (MartínRetortillo, 2016).

Table 5. Annual growth rates of agricultural labour productivity

\begin{tabular}{ccc}
\hline & $1950-1985$ & $1985-2005$ \\
\hline Spain & 4.94 & 4.96 \\
\hline Europe & 4.92 & 3.55 \\
\hline EU-9 & 5.93 & 3.28 \\
\hline O.E.M.C. & 4.49 & 3.50 \\
\hline
\end{tabular}

Calculation based on triennial averages of the agricultural production. Source: Own calculation based on FAOSTAT (2009) and FAO (1948-2004)

Land productivity also grew substantially, more than doubling in Western Europe and increasing nearly fourfold in Spain. The use of high-yield seeds or the intense use of fertilizers and pesticides were important factors causing this increase.

Finally, total factor productivity (TFP) also increased enormously. In Western Europe, it grew at an annual rate of 2 per cent between 1950 and 2005, in 
Mediterranean Europe at 1.8 per cent and in Scandinavian countries at 1.1 per cent. In the Spanish case, this increase was 2.4 per cent, constituting the highest TFP growth (Martín-Retortillo and Pinilla, 2015a).

\section{A Change in the Position of the Agricultural Sector in the Economy}

The process of agrarian change in western countries radically modified the sector's position in the economy in two fundamental aspects. First, the weight of the agricultural sector, which had been contracting in relative terms since the beginning of the industrialisation process in Europe, became much lower in terms of employment and GDP contribution. Second, agriculture had transformed from being a sector which used inputs that principally originated from the sector itself and sold its output directly to consumers to one which purchased the majority of its inputs from the industrial sector (mainly machinery, fuel, fertilizers and plant-protection products) and sold most of its output to the agri-food industry. In other words, there was an intense integration process of the agricultural and industrial sectors.

With respect to agriculture's declining weight in the economy as a whole, Spain followed the European trend, although with a delay. In 1950, the agricultural sector still represented almost 50 per cent of the workforce or contributed 30 per cent to GDP, while in 2005, agricultural workers represented 5.3 per cent of the total workforce and agricultural output contributed only 3.1 per cent to GDP.

In terms of the integration of the agricultural and industrial sectors, the importance of the latter has never stopped growing. According to the classification of the agri-food development stages established by Louis Malassis, the basic characteristic of the food production structure that evolves from a commercialised conventional food 
system into first an agro-industrial system and then into an advanced agro-industrial system is the superiority of the value added by industry with respect to the value added by agriculture (Malassis 1997, 238-9). In the case of Spain, in 1985 the value of production of the agri-food industry was 1.2 times more than final agricultural production. By 2002 it had grown to 1.7 times more (Gracia and Albisu 2004, 158).

\section{The Rise and Change of the Interventionist Agricultural Policies}

During the 1930s, the growth of public intervention in agriculture was a common phenomenon in Europe and other western countries, responding to the problems caused by the depression and clearly constituted a turning point (Federico, 2012). The interventionist policies applied by the Roosevelt administration in the United States with the passing of the 1933 Agricultural Adjustment Act were decisive and marked the beginning of the end for laissez-faire in agriculture (Libecap 1998). In Europe, there was also an overall tendency to attempt to mitigate the problems arising from the depression through public policies, such as protecting agriculture against foreign competition or implementing systems for controlling production or supporting farmers. A particularly significant feature in Europe was the inclination of the fascist regimes to exercise public intervention in agriculture in order to protect "certain 'higher values' that could not be left at the mercy of supply and demand" (Fernández-Prieto et al., 2014: 22). This intervention was focused on technocratic aspects that did not question the social order, always seeking to maintain the subordination of the sector to the political objectives of these regimes.

The Second World War merely prepared the ground further, as all the countries at war had no other option than to intervene in agriculture to ensure food supplies to their hard-pressed populations (Brassley et al., 2012). 
Reconstruction was marked by wartime food shortages and a dearth of foreign exchange, resulting in policies that encouraged self-sufficiency backed by public intervention in the form of guaranteed minimum prices and tariff protection for certain basic crops such as cereals (Milward 1984, 435-461; Fernández 2016). Different market regulation schemes were introduced in the majority of the market economies of Western Europe, while in Eastern Europe the states controlled the economy, partially or completely nationalising the land (Martín-Retortillo et al., 2016). The intervention policies implemented in agriculture led to an intense control of international agricultural trade which was not liberalised during this period and so there was a return to the pre1929 situation (González et al., 2016).

The signing of the Treaty of Rome in 1957 gave rise to the Common Agricultural Policy, which signalled the complete victory of intense public intervention in the European farming sector. National agricultural policies were progressively abandoned after 1962 (Ackrill 2000, 29-42; Fearne 1997, 11-33), and there was a tendency towards a homogenisation of these policies. Guaranteed prices, subsidies, income transfers to farmers and the promotion and placing of surpluses on the international markets not only put European agriculture on the road to self-sufficiency, but also reversed the trend that rendered the continent the world's main importer of agricultural produce (Pinilla and Serrano 2009).

The western European countries that had not yet joined the European Community adopted similar policies, while in the Eastern Bloc most countries imitated the Soviet model. In Spain, the Franco regime made the pursuit of self-sufficiency, particularly with respect to food, the principal symbol of national power. The instruments to achieve this were based more on fixed prices than the aspects mentioned above. However, the failure to achieve this self-sufficiency led the agricultural interventionism in Spain to 
abandon the strictly domestic-oriented policy and to follow the recommendations of international bodies, such as the Food and Alimentation Organization. Although Spain could not join the European Community until 1986, in the 1960s and 1970s there was a growing convergence of its agricultural policies with the supranational policies of the CAP (Clar 2008).

\section{Increased Capacity to Affect the Environment}

The improved productive efficiency of agriculture in western European countries, together with the major increase in its output have had serious environmental consequences. First, from an energy perspective, modern agriculture is highly inefficient. The Achilles heel of its high productive capacity is an energy output that is lower than the energy it consumes through its inputs (Naredo 1996, 303-412; Guzmán and González de Molina 2006). This has serious consequences for the land, particularly in the absence of an integrated use of land, with severe environmental effects (Tello 2010).

The second consequence, which is much more short-term, is the high polluting capacity of modern agriculture. The intense use of machinery and other inputs contribute considerably to the emission of gases and other contaminating particles. In addition, the intensive use of chemical fertilizers has a high polluting impact through the emission of nitrates and phosphates. The sector plays an important role in contributing to the deterioration of water quality.

Finally, in the European countries where irrigated farming is more extensively developed, the intense water regulation works that have been carried out have seriously affected the natural water cycle. This has occurred with the majority of the Spanish 
watercourses and the regulated river basins, affecting the population residing in them. Furthermore, the soil salinity, already high in some areas, has increased substantially as a consequence of the introduction of irrigation.

The Spanish agricultural sector has also experienced all of these environmental effects. With regard to energy, in 1950-51, agricultural and livestock output represented 30,308 million Kcal with a consumption of external inputs by the agricultural system (electricity, fuels, fertilizers, machinery...) of 4,962 million, with the quotient between the two being of 6.1. In 1999-2000, the final output had increased to 134,806 million Kcal, but the consumption of external inputs had increased to 106,184 million, representing a loss of energy efficiency of the system, now with a ratio of 1.27 (Carpintero and Naredo 2006, 539).

The management of water for agriculture through the extension of irrigation has also given rise to significant environmental consequences, principally: difficulties in preserving the river ecosystems, the overexploitation of groundwater resources, the deterioration in the quality of the water, a significant increase in salinity levels and the impact caused by the construction of hydraulic infrastructures (Ibarra et al., 2008) ${ }^{6}$.

Therefore, in some areas of Spain, such as La Mancha or Almeria, groundwater pumping rates are exceeding recharge rates, leading to the overexploitation of aquifers which also affects the health of the ecosystems (Esteban and Albiac, 2012a).

\footnotetext{
${ }^{6}$ The impact and consequences of water management go beyond the agricultural sphere as large infrastructures have also been built for hydroelectric uses, human supply or flood prevention. The consequences of these infrastructures have not only been environmental, they have also given rise to population movements or economic benefits. The study of this field, therefore, requires an integral perspective. For a study that approaches the topic in this way for the Ebro river basin, one of largest in Spain, see Pinilla (2008).
} 
With respect to the soil salinity of agricultural land, the intensification of the use of irrigation has affected the surface waters and by the beginning of the 1990s, thirtyseven per cent of this water was salty (Naredo and Gascó 1992).

Finally, the intensive use of chemical fertilizers and phytosanitary products in the irrigated areas of Spain since the end of the 1960s has greatly contributed to the widespread pollution of water by nitrates and phosphates (Sánchez-Chóliz and Duarte, 2003; Esteban and Albiac, 2012b).

\section{THE UNIQUE FEATURES OF THE SPANISH MODEL OF AGRARIAN CHANGE}

In 1950, the agricultural sector was still the largest employer in Spain. Although the country's agricultural sector had experienced significant transformations in the first third of the twentieth century, following the trend of other developed countries, there is no doubt that the situation in the Spanish rural context was unusual (Barciela et al., 2001; Christiansen, 2012; Clar and Pinilla, 2009; Clar, Martín-Retortillo and Pinilla, 2016). After showing how the principal aspects of the Spanish agrarian transformation after 1950 coincided with those of the Western European trend we will now analyse its distinctive characteristics.

Agricultural Policies and Institutions during the Franco Dictatorship

Until 1975, Spain lived under the dictatorship of General Franco, with the support of the Spanish fascist party (Falange Española) and other conservative forces following the victory in the Civil War in 1939 of the military rebellion against the Republic. In Western Europe only Greece and Portugal also had dictatorship regimes, 
although the intensity and scope of the repression and violence suffered in Spain was much more pronounced.

In December 1946, the General Assembly of the United Nations, in its resolution 39(I), recommended the withdrawal of the ambassadors based in Madrid due to the fascist-style regime of Franco and his collaboration with Nazi Germany and Fascist Italy. The ration books that were introduced at the beginning of the war were maintained and hunger was not a strange phenomenon in Spanish society as the agricultural sector subject to extreme government intervention was unable to adequately feed the population. As a result, a large part of the exchange of food took place on the black market, mostly benefiting the wealthier landowners (Christiansen 2005). The technological backwardness gave rise to a decline in agricultural productivity which fell to levels similar to those of the beginning of the century (Clar and Pinilla 2011).

However, in the 1950s things gradually began to change, at least in economic terms, although not so much on a political level where the most noteworthy change was a softening of the repressive policy once the dictatorship felt secure, especially after having eliminated the anti-Franco guerrilla resistance which was highly active after 1945. So, after 1951, there was an important shift in the agricultural policy of Franco's regime with a clear intention to take advantage of the technological innovations that were internationally available and to improve productivity. At the same time, the isolation of the Franco regime was coming to an end due to the intensification of the cold war. In November 1950, the General Assembly of the United Nations voted for the repeal of Resolution 39(I) and in 1955 Spain joined the organisation. The signing of the concordat with the Vatican and the bilateral treaty with the United States in 1953 was crucial in ending Spain's international isolation. Even so, its reintegration into the 
political framework of the western countries was not complete as Spain's political regime excluded it from being included in the European integration process.

From a social point of view, the agrarian reform carried out in the 1930s during the Republican period had been reversed, with the return of land to the former owners who had supported Franco's forces during the Civil War. On the other hand, in the 1940s, the repression, imprisonments and executions were still commonplace in the rural areas, with the majority of the victims being farmers who had supported the left-wing parties and their policies or the trade unions during the years of the Republic. The opposition to the agrarian reform that had been approved during the Republican years and other measures taken to improve the situation of those farmers with fewer resources were essential elements in the programme of the rebellion against the democratic regime. It is not surprising that one of the first measures, even before the end of the war, was to revoke this agrarian reform. From that moment, Franco's agricultural policy was no longer based on social reform aimed at distributing the land and improving the living conditions of peasants, particularly in the south of the country, but became a technical reform that only questioned the feasibility of the smaller farms and not the large estates $^{7}$.

In the 1940s, the influence of the regime's fascist ruralist ideology meant that the continuance in rural areas and the traditional values of the agricultural activity were valued very highly despite the harsh economic, social and political conditions at that time (Silvestre and Serrano, 2012; Cabana and Gadea, 2014). However, from the beginning of the 1950s, Spain's agricultural policy was clearly biased towards

\footnotetext{
${ }^{7}$ The Minister of Agriculture at that time could not say it more clearly: "all of the afflictions of our agriculture have been frequently attributed to the poor distribution of rural property, but most of all to one of its aspects, the "large estates", forgetting or leaving in a secondary place the opposite kind of property, that of extreme fragmentation to which more than half of the country is subjected" (Cavestany $1955,9)$.
} 
productivity and it was considered that a large part of its active population could be sacrificed in order to achieve an accelerated modernisation. This characteristic is not unique to Spain and was shared by the other Western European countries between 1940 and 1980, with the objective of improving the production of food with the express support of state policies (Evans 2001, 45).

A unique and characteristic feature of the Spanish case was the special conditions under which these productivity policies were implemented. The agricultural modernisation policy, aimed at boosting Spain's economic development, was executed by Franco's regime without taking into account other social or environmental considerations. The contribution of the agricultural sector to the so-called "Spanish miracle" of the $1960 \mathrm{~s}$, basically responded to the two fundamental objectives of the model: to supply cheap food to the population and labour for industrial and urban expansion (Clar and Pinilla 2009). To do this, a whole series of agricultural and other measures were implemented which, due to the non-democratic nature of the regime, were not subject to debate and met hardly any effective resistance ${ }^{8}$. While the agricultural modernisation processes in the European democracies took place within a context of free participation by civil society (unions, cooperatives, entrepreneurs...) and the consolidation of the welfare state, this was not the case in Spain where this modernisation was facilitated by the authoritative nature of the State with very high social and environmental costs and without parallel measures that would increase the income of farmers (Lanero and Freire 2011, 14 and 24). This does not mean that measures were not taken in other Western European countries that could have had serious environmental consequences. The fundamental difference is that in these

\footnotetext{
${ }^{8}$ The policies regarding the construction of reservoirs or reforestation are paradigmatic examples. Not only was the opinion of the people directly affected by these policies disregarded, but when necessary they were expelled from their places of origin with hardly any compensation.
} 
countries, the measures were taken by democratic governments with parliamentary control, while in Spain the possibility of criticising these actions or opposing them was very scarce and protesting action only began to emerge at the end of the 1960 s and the 1970s (Corral, 2014).

Therefore, the transformation process of the Spanish agrarian model was carried out and the modernisation and its effects met very little effective resistance. We will now focus on the main institution that could have conducted this opposition to this stark productivism experienced by the Spanish rural environment: the agricultural unions. The workers unions had been declared illegal and the regime established a single vertical union which in the countryside was the Hermandad de Labradores $y$ Ganaderos [Brotherhood of Farm Workers and Livestock Farmers]. This constituted an important difference with respect to the situation before 1936 and in the rest of the developed European countries. While in the other countries, public authorities and agricultural organisations designed the change process, in Spain the modernisation arose from decisions made at the top of the regime's political elite which depended on the internal and external economic needs (Moyano 1994, 235). Not even the clandestine unions, emerging at the end of the 1960s, were able to question the model of agricultural development through the legally established channels, with the regime's only response being political repression (Bernal 1993, 157-8).

Prominent examples of agrarian change decided from the top and with little or no possibility for those affected to intervene are the land consolidation policy, the hydraulic policy and the agricultural extension. All of these measures were the result of a very specific political and ideological substratum: the agricultural programme of the

\footnotetext{
${ }^{9}$ The case of Fuentes de Andalucía (Seville) is highly illustrative: In November 1968, a group of farm day labourers went to the Ministry of Agriculture to report the poor performance of a latifundia, and requested that it was expropriated and divided among the farmers. The labourers involved were subsequently condemned for unlawful association and were given prison sentences.
} 
Spanish fascist party (la Falange). Opposing the agricultural reform of the republican period, the principal agricultural ideologists conceived a technical reform that included the establishment of appropriately-sized farms, the expansion of irrigation, the undertaking of large hydraulic works, the division of land into plots and the establishment of tenant farmers. Influenced first by the social and catholic doctrine and Italian agrarianism (Fascist and Christian democrat) and then by the agricultural expansion in North America, a restructuring process was developed, designed from the top and sold as a policy to: primarily support farmers, free from any social class connotations $^{10}$, and from 1955 to defend family farming heritage through more efficient and profitable operations (Gómez Benito, 1995: 76,106-112y 48).

In line with the previously mentioned technical agricultural reform, the process of consolidating land responded to the objective of eliminating smallholdings ${ }^{11}$. Therefore, while in France the land parcelling process affected mainly the large farms in the north of the country (Dovring 1965, 49), in Spain, this policy mostly affected the small farms in the north of the country, which had to restructure themselves in order to comply with a consolidation law which was initially voluntary but then became compulsory. Meanwhile, the large estates in the south remained mostly unaltered.

On the other hand, the expansion of irrigation was not the sole objective of the hydraulic policy. Another fundamental objective was the development of hydroelectric energy. Therefore, the building of reservoirs was prioritised over any other consideration, including certain rural and agricultural villages which would have to be

\footnotetext{
10 The fascist discourse disregarded the class distinctions in the rural environment and even those between large and small estates (latifundios and minifundios). From this perspective, farmer always meant owner, so that farm labourers had to become owners of a small plot of land or orchard (Gómez Benito, 1995. 59).

11 Again, the Minister of Agriculture of the day: “...as the primary objective of the agricultural polity of eliminating the structural difficulties that hinder the development of the new agriculture; the Land Consolidation Law was established (...) Until we eliminate the "small farms" of the northern half of Spain we cannot talk about a modernisation of its agriculture." (1955, 309).
} 
flooded. Villages and farmland became waterlogged, leading to the displacement of the population (Herranz 1995). There was no possibility of the costs and benefits of these constructions being discussed within a democratic context. The government made decisions based on strictly technical criteria and there was no possibility of questioning them. Furthermore, the compensation paid to the displaced communities was very low and the local authorities usually led the negotiations in such a way so as to benefit their own interests (Lanero and Cabana 2014, 239-41).

The absence of an agricultural extension institution in Spain led to the creation of the Agricultural Extension Service (SEA) ex novo in 1955, based on the North American model and the guidelines of its experts with respect to the process carried out by the USA in Latin America. The North American extensionist influence was not unique to Spain, bearing in mind that American aid programmes in Europe during the post Second World War period included such initiatives. However, the Spanish model, contrary to those of other countries such as France, constituted a type of "regulatory" extension, whereby those affected did not intervene in the co-management of the agricultural modernisation process as was the case of France after 1959 (Sánchez de Puerta 1996, 373-5). Some authors point out that from the end of the 1960s, the Spanish agricultural extension had given rise to a model with a certain level of co-management between technical experts and farmers (Gómez Benito and Luque 2007, 144-5). However, this co-management was limited by the technical-productive objectives. Any attempt to go a step further and include social objectives clashed with the local authorities of Franco's government. In some cases this led to situations where extension technical experts had to move to a different region due to their affinity with the situation of the farmers (Gómez Benito and Luque 2007, 146; Sánchez de Puerta 1996, 427). 
The impossibility of the farmers having their own political voice, which can be seen in the examples above, translated into insignificant amounts of economic support. In other European countries, the public policies substantially increased the income of farmers (Spoerer 2015). An analysis of Franco's government spending on agriculture gives us a clear picture. Only wheat producers received subsidies from 1963 to prevent a fall in their income, given that wheat was considered a priority product. But the first project designed to truly improve the situation of the farmers as a whole, at the end of the 1960s, was concerned with productive aspects. So, irrigation represented half of public investment, land consolidation accounted one third, while spending on R\&D, education and professional training represented just 2 per cent of the total. With respect to subsidies granted to Spanish farmers between 1967 and 1975, those allocated to payments related to production (including price support) fluctuated between 21 and 33 per cent, while those related to the use of inputs oscillated between 58 and 75 per cent, with a clear predominance of the purchase of fuels (Fernández 2008, 20-22).

Graph 1. Nominal Rate of Assistance for the Spanish Agricultural Sector, 1956-2005 


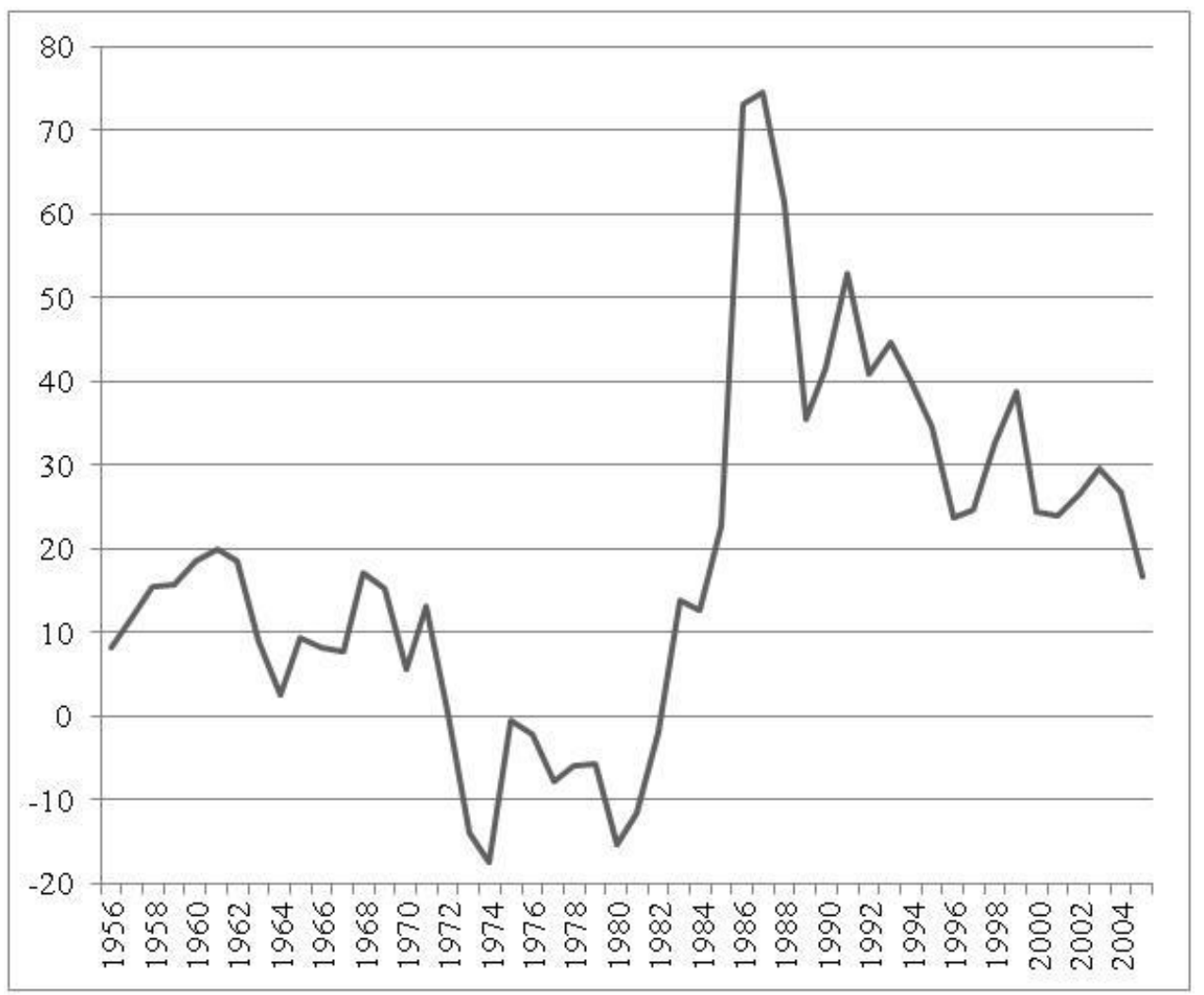

The nominal rate of assistance (NRA) is defined as the percentage by which government policies have raised gross returns to farmers above what they would be without the government's intervention (or lowered them, if $\mathrm{NRA}<0$ ). NRA is expressed as a percentage of the undistorted price.

Source: Anderson and Valenzuela (2008).

The level of support enjoyed by Spanish farmers was very low and was even negative for some years. Furthermore, it declined in comparison with that of the European Community countries. Expressed as percentages with respect to the EEC averages, the support received by Spanish farmers in 1970 was only 23 per cent of the EEC average per farmer; it was even lower with respect to the EEC average per farm at 19 per cent and even lower still (14 per cent) per hectare (Ministry of Agriculture 1971, 10). Graph 1 confirms this trend of low protection for Spanish farmers. Based on the difference between internal and external prices, Josling's calculation of the gross subsidy equivalent of assistance per person engaged in agriculture placed Spain at the lowest levels, and in the period 1970-1985 negative protection levels were recorded. 
This situation did not occur in any other country of this author's sample. In contrast, Spain's level of assistance to farmers in the period 1965-69 was more than ten times lower than in Italy: 230 vs. 2,350, both in constant 2000 US dollars (Josling 2009, 156). In Graph 2, we can observe how farmers in Western Europe already received a substantially higher level of assistance than those in Spain in the 1950s. The gap continued to widen until it reached enormous levels just before Spain joined the EU. Spain's EU membership and its integration into the Common Agricultural Policy (CAP) considerably reduced this gap in terms of government support, reducing it to a small amount attributable to the different production structures of the different types of agriculture.

Graph 2. Difference between the assistance given to agriculture in Western European countries and Spain, 1955-2004 (expressed as the difference in percentage points of the NRA to agriculture)

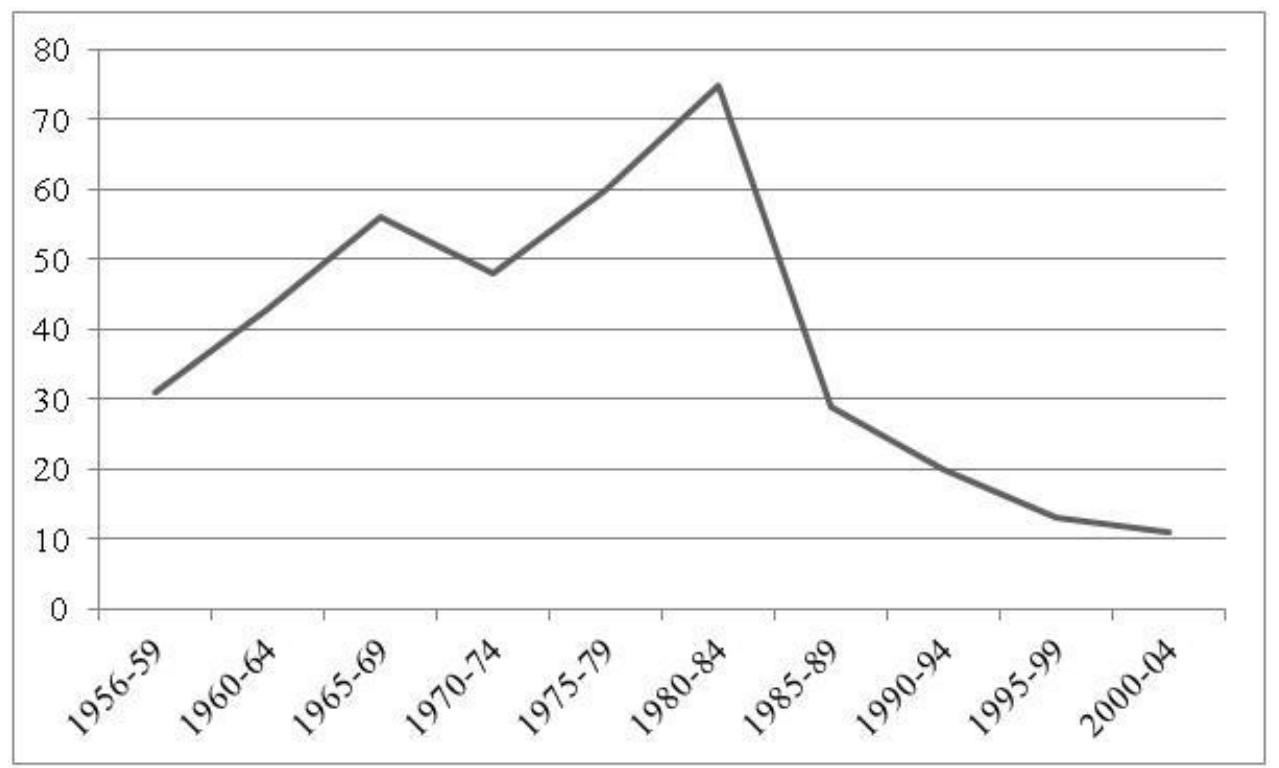

Source: Calculation based on Josling (2009), p. 154.

Given the above-described productivist logic applied by a non-democratic regime, these dynamics are not surprising. However, Josling's figures show that the problem of 
a low level of assistance for Spanish farmers was not a feature exclusive to the dictatorship, but persisted into the early decades of the democracy. Whichever protection indicator we use of the many offered by this author, only in the middle of the first decade of the twenty-first century did agricultural support in Spain reach the same level as Western Europe as a whole and that of the EU member states.

In short, the policies related to agriculture and the rural environment during Franco's dictatorship stood out not so much for what they did but for what they did not do. As in other countries, there were policies directed at land consolidation and rural planning and agricultural extension programmes, although in Spain the measures were more regulatory and imposed from above. But while in many of these countries the disputes and sharing of common interests between the politicians and agricultural institutions (unions, associations...) gave rise to high levels of support for farmers (Sheingate 2001), in Spain the non-democratic context, the enormous discretionary power of government policy and the weakness of the rest of the institutions translated into an implementation of agricultural productivism with no checks and balances, and with hardly any compensation for those affected by it. The arrival of democracy in 1977 did not bring a substantial improvement to this scenario, due to fact that the agricultural and rural institutions had to be reconstituted after a forty-year absence and also because the principal objective of Spain's democratic agricultural policy was productive convergence with the CAP with a view to joining the EU.

\section{The Rapid Development of Livestock Production}

Another distinctive feature of Spain's agrarian change after the Second World War was the growth in its livestock production that was significantly faster than that of the 
rest of the Western European countries. This is particularly surprising if we take into account that the ecological conditions of the majority of the Iberian Peninsula are highly unfavourable for the development of a large livestock population due to its extreme aridity. Traditionally, to adapt to these conditions there was a predominance of extensive sheep farming as these animals are ideal for rough grazing. Furthermore, until the middle or the end of the nineteenth century, depending on the different regions, transhumance was a way of overcoming these climatic restrictions ${ }^{12}$. Moreover, mules predominated over horses or oxen as draught animals in agriculture. Despite this, the proportion of total agricultural production attributable to livestock production was much lower in Spain than in the countries of northern or central Europe (Reis 2000, 27). Even as late as 1961, the participation of livestock output in Spain's agricultural production was below 25 per cent, when in the leading countries of Western Europe it represented over 50 per cent. Subsequently, the weight that livestock production carried of total agricultural production increased by 13 percentage points in Spain but did not vary in Western Europe; therefore Spain converged with European levels.

Table 6. Evolution of the participation of livestock farming in the agricultural production, 1950-2005 (percentage)

\begin{tabular}{crrrrr}
\hline & 1961 & 1970 & 1985 & 1995 & 2005 \\
\hline Spain & 23.0 & 30.4 & 32.9 & 38.0 & 36.8 \\
\hline Europe & 46.3 & 46.9 & 49.0 & 49.3 & 47.7 \\
\hline EU-9 & 52.4 & 51.8 & 54.4 & 53.9 & 51.9 \\
\hline O.E.M.C. & 26.5 & 27.7 & 31.6 & 33.7 & 32.7 \\
\hline
\end{tabular}

Source: Own calculation based on FAOSTAT (2009)

Until 1985, the evolution of Spanish livestock farming followed the Western European trend. However, after this, Spain experienced a rapid acceleration while in the

\footnotetext{
${ }^{12}$ Transhumance was when flocks grazed in the mountainous regions in the summer and were moved to the valleys and plains in the winter. The most well-known organisation overseeing this process was the Mesta
} 
most part of the continent livestock farming declined or remained stagnant. Graph 3 shows that in 1955 the UK had five million livestock units more than Spain and still in 1985 this distance was close to five and a half million. In 2005, however, the difference between the two countries was only 635,000 .

Graph 3. Evolution of weighted livestock units, 1950-2005.

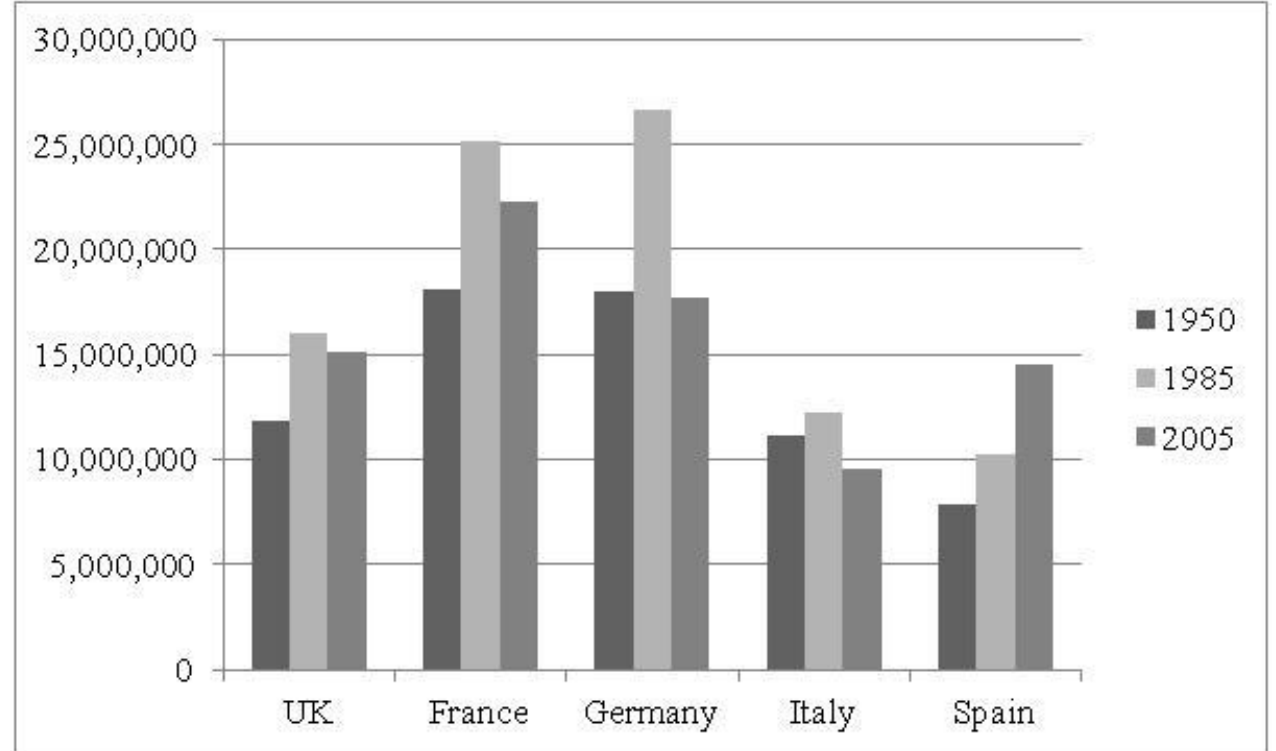

France, Germany, Italy and the UK were the countries with the highest livestock units in Western Europe.

Source: Own calculation based on FAOSTAT (2009) and FAO (1948-2004)

This strong expansion in livestock production represented 47.6 per cent of the total increase in Spain's agricultural production from 1970, and 62.5 per cent between 1985 and 2005. Furthermore, this expansion was dominated by intensive livestock farming, focused on granivores (poultry and porcine) which increased from 48.6 per cent of the total tonnes of meat produced in Spain in 1961 to 75 per cent in 1985. It is true that the boom in intensive livestock farming was a feature common to many western countries, but of the EU countries studied, only Finland exhibited a change in its livestock structure as intense as in Spain (Table 7). 
Table 7. Percentage of granivores of total tonnes of meat produced

\begin{tabular}{|c|r|r|r|}
\hline & \multicolumn{1}{|c|}{1961} & \multicolumn{1}{|c|}{2005} & \multicolumn{1}{c|}{ Difference } \\
\hline Austria & 68.3 & 74.2 & 5.9 \\
\hline Finland & 47.1 & 77.1 & 30.0 \\
\hline France & 46.2 & 69.1 & 22.9 \\
\hline Germany & 67.0 & 80.9 & 23.9 \\
\hline Greece & 31.9 & 53.7 & 21.8 \\
\hline Italy & 44.5 & 63.5 & 19.0 \\
\hline Portugal & 57.0 & 79.4 & 22.4 \\
\hline Spain & 48.6 & 80.5 & 31.9 \\
\hline Sweden & 60.5 & 70.3 & 9.8 \\
\hline UK & 46.3 & 67.5 & 22.2 \\
\hline Western Europe & 58.3 & 77.0 & 21.7 \\
\hline
\end{tabular}

Source: own calculation based on FAOSTAT (2009)

This strong commitment to intensive livestock farming, which broke away from the traditional extensive model which had prevailed in Spain, was related to the regime's policy decision to offer Spaniards meat at affordable prices. Given the limited availability of necessary raw materials, animals and fodder, and the absence of an appropriate industrial structure, Franco's government implemented State trade policy in a way so as to facilitate the entry of new breeds of animal (broiler chickens and Large White or Landrace pigs), and large amounts of soya and corn from the United States, while it opened the door to capital investments of large fodder multinationals in Spain (Clar 2013). The relationship between these large transnational companies and small Spanish businesses enabled the rapid implementation of an agro-industrial model based on vertical integration in which the multinationals were the strongest link and the livestock farmers the weakest link in the production chain (Clar 2010).

Livestock farming was not exempt from the productivist obsession. The large capitalisation required soon gave rise to a strong concentration of production and a significant increase in the size of businesses (Ríos and Coq 2014, 18). The intensive 
livestock farms were affected and between 1987 and 1997 the number of pig farms fell by 70 per cent while the livestock population grew by 255 per cent (Arnalte 2002, 398). A study conducted in the mid 1990s reflects how the degree of specialisation increased significantly with the increase in the economic size of granivore farming. It was not the same case for herbivores in Spain (Ruiz-Maya 1994, 45). At the same time, the development of intensive livestock farming substantially altered the production map in Spain, with pig farming being the clearest example. At the beginning of the $1960 \mathrm{~s}$ production was concentrated in the traditional regions (Andalusia, Extremadura, Galicia), but by the 1980 s, production had clearly shifted to the industrial areas in the east (Catalonia, Aragon) close to the major consumption centres (Barcelona, Valencia).

To a large extent, this emphasis on size and economies of scale, together with the opening up of the country to foreign trade between 1955 and 1995 improved Spain's position in the international meat market. In the 1950s, Spanish meat exports represented only 21 per cent of the imports, but in the first decade of the twenty-first century they represented 209 per cent. The growth in meat exports was spectacular, increasing from 0.4 per cent of total Spanish agricultural and food exports in the $1950 \mathrm{~s}$ to 12 per cent in the period 2008-2011 (Clar et al. 2015, 164-7). This is not surprising if we take into account that, only China, the United States and Germany had a pork production that was larger than Spain's in 2010.

\section{The Crucial Importance of the Expansion of Irrigation}

A third distinctive feature of Spain's agricultural change is the enormous increase in irrigated crop production. In order to understand this concept it is necessary to take into account the arid conditions of most of the Spanish territory (with the exception of the Atlantic northern strip where there is a much higher level of humidity). Traditionally, 
this meant that Spain's land productivity was much lower than in the other Western European countries. Furthermore, the innovations that had been developed initially in seventeenth-century England (mixed farming) and had spread to many other European countries in the nineteenth century could not be adopted in Spain due to the climatic conditions. The elimination of fallow land and its replacement with fodder legumes was unfeasible because these plants required an amount of water that was not usually available in most of Spain. After the Civil War, the Franco regime saw the expansion of irrigation as a way to increase agricultural productivity without affecting the redistribution of land and it intensified a policy initiated at the end of the nineteenth century. From 1977, now within a democratic framework, the commitment to the expansion of irrigation continued (Duarte et al. 2014).

Irrigation constituted the principal area of public agricultural investment in Spain between 1955 and 2005. The real net capital stock (in thousands of euros of 2000) devoted to basic water infrastructure and irrigation grew from 2,448 million euros in 1955 to 25,279 million euros in 2005. Investment in water infrastructure was particularly intense between the 1960s and early 1990s. During this period, the basic irrigation water infrastructure accounted for over 20 per cent of the Spanish public infrastructure investment and in certain periods close to or above 25 per cent (Cazcarro et al. 2015a, 5109-12).

With respect to surface area, the number of irrigated hectares increased from 1.3 million in 1950 to 3.8 million in 2005. This expansion was particularly fast until 1982 when an area of three million hectares of irrigated land was reached. In this way, the percentage of Spain's irrigated land of the total irrigated area in Europe grew from 15.3 per cent in 1950 to 20.4 per cent in 2005 , growing at a faster rate than in other countries. The two European countries with the largest irrigated areas were Italy and Spain which 
practically had the same area in 2005, although in 1950 Italy had an advantage of two million hectares, more than doubling Spain's irrigated area (Martín-Retortillo and Pinilla 2015a). Such an enormous growth in the irrigated area, particularly in the driest areas of Spain, which is where crop production has increased the most, raises serious doubts about the economic and environmental sustainability of continuing this expansion (Cazcarro et al. 2015a). Today, Spain is among the countries with the largest irrigated areas and with the most environmentally stressed water bodies and largest water footprints in the world. Between 1930 and 2008, the increase in blue water embodied by Spanish agricultural production was $6.5 \mathrm{~km}^{3}{ }^{13}$ (Duarte et al., 2014: 205). A significant part of the increase in the water footprint of Spanish agriculture is due to the considerable increase in its exports. Between 1966 and 2008, 60.6\% of the increase in Spain's blue water footprint was caused by the increase in its net agricultural trade balance (84.8\% if we only consider exports) (Duarte et al, 2016: 268).

The large expansion of irrigation in Spain has had a significant impact on the dynamics of agricultural production. Today, Spanish agriculture is a sector which is mostly based on irrigated crops. In 1955, almost 42 per cent of Spain's crop output was produced from irrigated land and in 1980 this had increased to 50 per cent. In fact, in 2006, the output produced from irrigated farming represented 65 per cent of the total. The analysis of the production increases over the fifty-year period after 1950 confirms this trend. More than two thirds of the increase in crop production experienced by the Spanish agriculture sector between 1955 and 2006 was due to the extension of irrigated land (Cazcarro et al. 2015b). In the twenty-five year period between 1955 and 1980, almost half of the total increase of Spain's crop production was due to irrigation. Subsequently, this trend has continued strongly and the increase in irrigated crop

\footnotetext{
${ }^{13}$ Blue water is the surface or ground water that evaporates during a production process.
} 
production has more than compensated for the decline in the production of rainfed crops (Graph 4).

The increase in irrigated land significantly contributed to the huge growth in Spain's crop production during the second half of the twentieth century. Production increased due to the replacement of dry crops with irrigated crops and the resulting larger harvests. Productivity also increased mainly due to technological innovation. (Cazcarro et al. 2015b, 346).

Graph 4. Percentage of irrigated crop production over total crop production in Spain, 1955-2006.

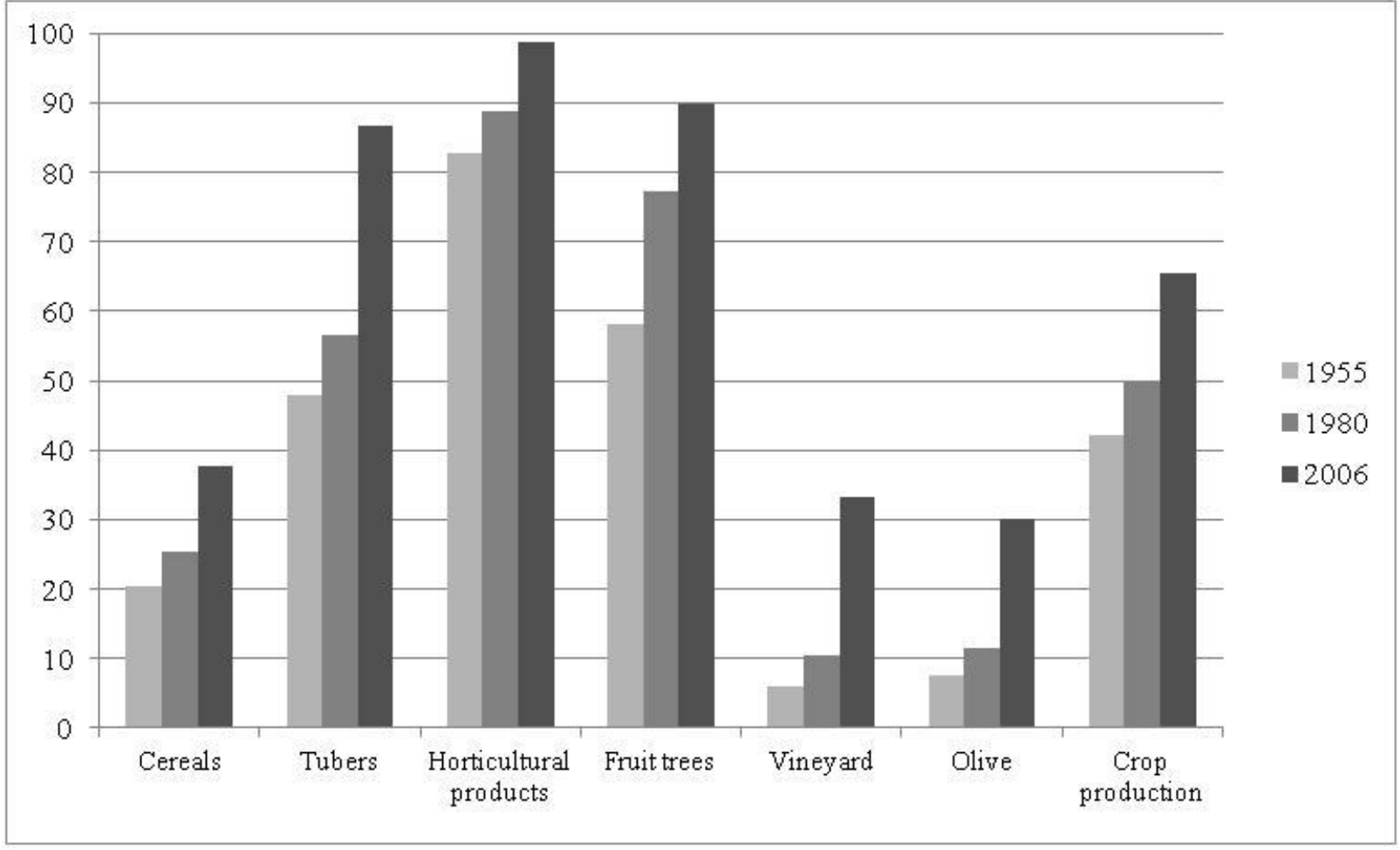

Source: Cazcarro et al (2015b).

The progress made in irrigated crops is reflected in the distribution of the agricultural product. In 1955, the structure was clearly dominated by cereals; by 2006 , this dominance had been transferred to fruit trees and cereals had dropped to fourth 
place, immediately behind horticultural products. In other words, these are the products where irrigation has expanded the most and which now occupy the leading positions in the Spanish production structure. In fact, the dominant production areas in the far southeast of Spain (the provinces of Almeria and Murcia), which barely accounted for $2 \%$ of the vegetable crop area in 1950 , represented $25 \%$ of the total in 2010 . The case of Almeria is particularly interesting. It is a very dry province which has intensely developed protected irrigation (more than half of the total surface area of this type in 2010) through the use of vegetable greenhouses. Although the farms in this province are small, the investments in technology and infrastructure to enable farmers to exploit the groundwater have had a successful outcome in terms of income and population (Corominas, 2001:14-15).

However, in general terms, irrigation favours a more intensive type of agriculture which complemented the emphasis placed on specialisation and the greater size of farms (Ruiz-Maya 1994, 44). The implementation of irrigated farming required a capitalisation of farms which many traditional farmers could not assume and stimulated the search for economies of scale to ensure a return on investment.

In short, the huge expansion of irrigation, derived from the dictatorship's emphasis on hydraulic policy and the construction of reservoirs, in turn responded to a productivist model which largely determined the evolution of Spanish agriculture, fundamentally nourishing the strong growth of its output and explaining the changes in its production structure since the 1960s.

The Persistence of Growth in Agricultural Production 
During the period 1950-2005, the Spanish agricultural product grew more intensely than in the rest of Europe, the EU-9 and any other western European country (Table 8 and Graph 5). However, the most characteristic feature of the Spanish model is not this faster growth rate but its persistence over time, unmatched by any other Western (or Eastern) European country (Martín-Retortillo and Pinilla 2015b). Agricultural production in Western European countries stagnated from the mid 1980s. A fundamental element causing this stagnation was the implementation of the MacSharry Reform of the CAP in 1992 which represented a change in philosophy of this policy. The CAP was no longer a price policy but a direct income support policy, with a clear decrease in the stimulation of production. Also at the beginning of the $1990 \mathrm{~s}$, the inclusion of agriculture in the GATT Uruguay Round marked the beginning of a liberalisation process in the international markets of these products which affected the position of Europe.

Table 8. Annual growth rates of agricultural production, 1950-2005.

\begin{tabular}{lcc}
\hline & $1950-85$ & $1985-2005$ \\
\hline Spain & 2.85 & 1.29 \\
\hline Europe & 2.43 & -0.08 \\
\hline EU-9 & 2.19 & -0.04 \\
\hline O.E.M.C. & 1.83 & 0.22 \\
\hline
\end{tabular}

Source: Own calculation based on FAOSTAT (2009) and FAO (1948-2004)

In contrast to the stagnation in Western European countries, the rapid growth rate in Spain brought the level of Spanish agricultural production close to that of larger countries such as Germany, France or Italy. In 1960, Spanish agricultural production was just below half that of Italy and 2.3 times less than France's production. By 1985, Spanish production had reduced the gap substantially with both countries. Finally, in 
2005, the volume of Italian production was only 1.1 times more than Spanish production and that of France was 1.5 times greater.

Graph 5. Agricultural production in Western European countries vs. Spain (ratio of other countries agricultural production over Spanish agricultural production)

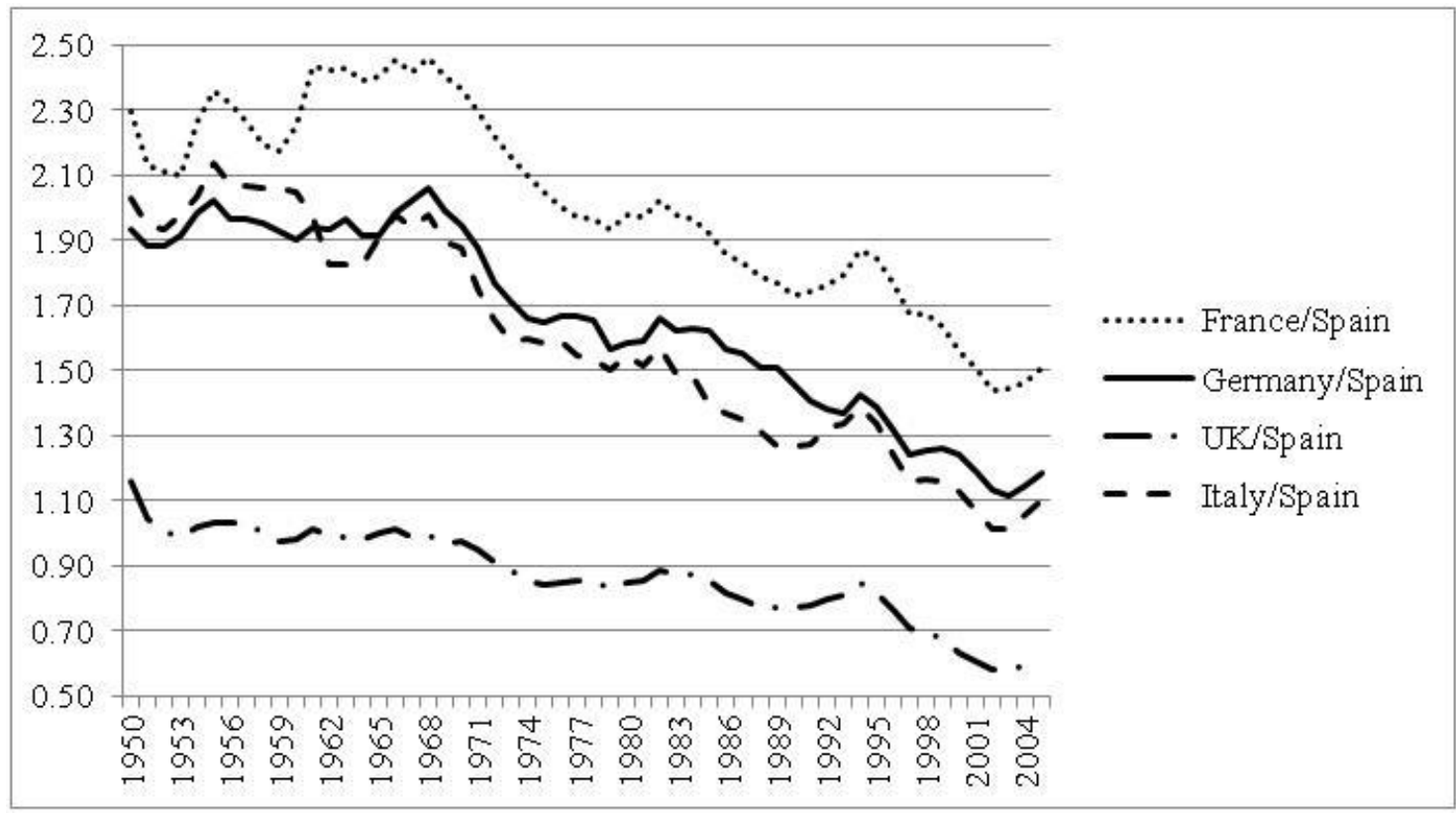

France, Germany, Italy and the UK were the countries with the highest agricultural production in Europe.

Source: Own calculation based on FAOSTAT (2009) and FAO (1948-2004)

How can we explain this persistent growth in production when that of the other Western Europe countries was behaving so differently? In our opinion, there are two causes. First, despite the afore-mentioned change in the CAP, the entrance of Spain into the EU represented a significant increase in the support given to Spanish farmers, which implied a significant stimulus for expanding production (see Graph 1) ${ }^{14}$. Second, after the transition period had come to an end, access to the EU market boosted Spanish exports of agri-food products enormously, which constituted a further stimulus to expand the production of exportable produce.

\footnotetext{
${ }^{14}$ Despite the change in the orientation of the CAP, many Mediterranean products, such as olives or grapes were not significantly affected by it (García Grande 2005, Neal 2007).
} 
Just at the time when Spain joined the EU, the CAP abandoned the previous productivist logic, turning to one which implied breaking the link between aid to farmers and production incentives. This, in itself, represented a serious problem for the Spanish agricultural sector which, without having resolved its structural deficiencies had an over-sized production capacity which translated into surpluses in many products. In addition, during the period 1986-1989, the CAP measures were not fully implemented and family-run farms received European investments and subsidies to facilitate their adaptation (Extezarreta 2006, 307). The European policy of subsidies per product unit reinforced the process of agricultural intensification and led to improved productivity and income for farmers; but it also aggravated the problem of surpluses and gave rise to a transfer of income from the consumers to the farmers, which could not last for very long (Genovés 1994, 174).

Therefore, from 1990, the full implementation of the CAP led to a fall in the income of farmers in constant terms, while the number of people who were leaving the rural context increased. Between 1986 and 1996, Spain's agricultural workforce fell by almost 850,000 people, due to the rationalisation of production policy and the support granted to those who abandoned the activity. A considerable part of those who remained in the countryside did so thanks to the subsidies. As the conclusion of a study on the first decade of Spain's EU membership comments: "Spanish agriculture, which entered the EU believing that its competitiveness would be the key to opening the door to the European markets, has become a "compensated" or "subsidised" agriculture" (Lamo de Espinosa 1997, 141, 154 and 162).

In short, the Spanish agricultural sector ended up with a dual reality, similar to that of the most important European countries: there were both economically small family farms, highly dependent on subsidies and economically large corporate farms in which 
production and an increasingly large proportion of the CAP support were concentrated (Extezarreta 2006, 294 and 308). In contrast with the stark productivism developed by the Franco regime, other "post-productivist" considerations, such as environmental issues or sustaining the rural population, have entered the agricultural equation. This has given a certain degree of stability to the income of family-run farming, which is developed both full time or, as is usually the case in Spain, part-time. All of these factors have slowed the intense process of the disappearance of farms which began in the 1960s in exchange for a dependency on subsidies which does not guarantee their future.

Graph 6. Spanish exports of agricultural products, 1951-2005 (index of volume calculated in \$ USA of 1980)

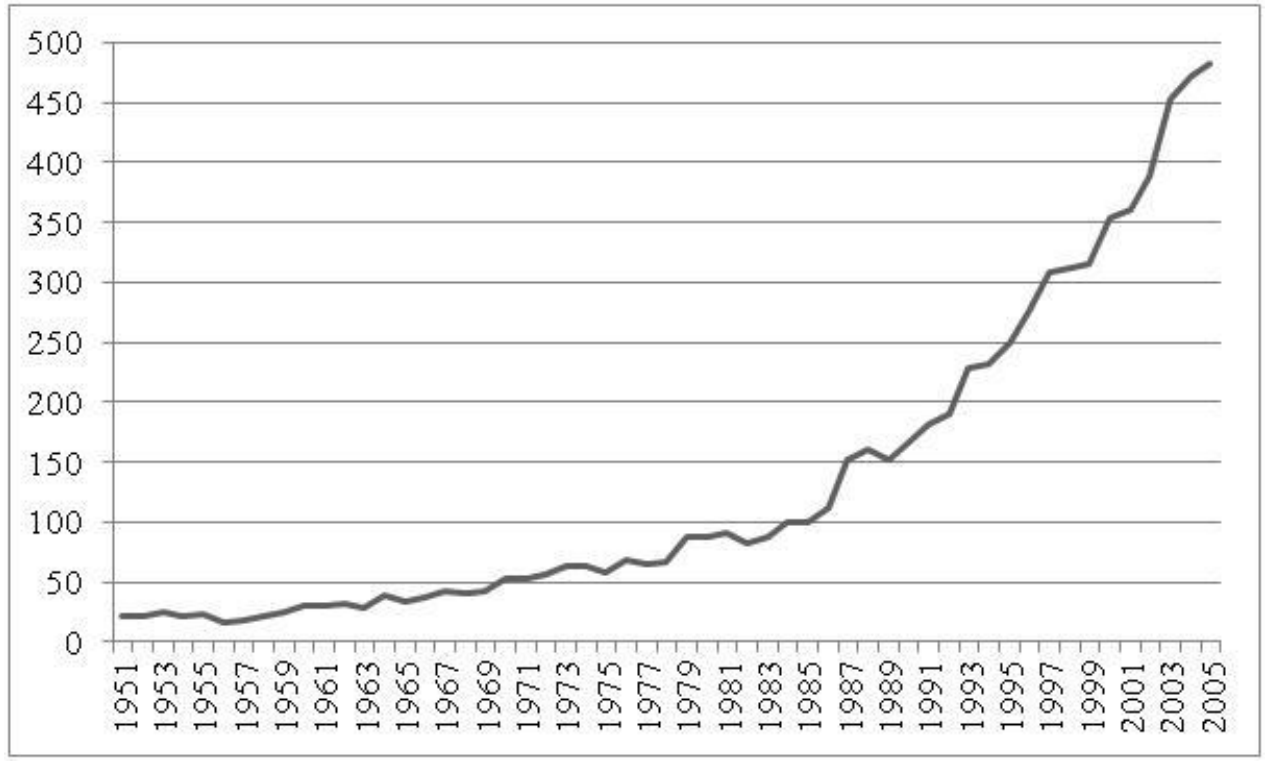

Source: Clar et al. (2015)

Furthermore, gaining access to the European market initially represented excellent trade opportunities for those products, particularly Mediterranean products, in which Spanish agriculture was competitive. Internal trade between member nations increased 
substantially after the abolition of internal tariffs, and even more so with the creation of the single market or monetary union. Agricultural trade was no exception (Serrano and Pinilla 2011). Spain, therefore, initially benefited from accessing a market with enormous potential under more favourable conditions. But more interesting than these benefits, which we could classify as being static derived exclusively from trade liberalisation, is that the Spanish agri-food sector became highly dynamic after Spain's accession, introducing technological improvements and adapting to the new conditions of demand and consumer tastes. In short, although they were relatively small, Spanish agri-food companies learnt how to grow and improve their productivity (Serrano et al. 2015). Consequently, agricultural production, integrated in the complex agri-food sector, has grown, and Spain has become one of the world's leading food exporters. As we can observe in the Graph 6, agricultural exports grew at a very fast rate after 1985, and their volume multiplied almost five-fold in only twenty years.

Despite the huge efforts made from the mid 1950s, Spanish agricultural productivism had managed to adapt its agricultural sector through the total or partial abandonment of the farming activity without the dimensional restructuring that had occurred in other countries such as France or Germany which would have rendered family farms viable (Barceló 1994, 222-3). Only the large estates were transformed into large agricultural companies with sufficient capacity to compete in Europe. And this reality of the Spanish rural context became even more pronounced after the MacSharry Reform of the CAP.

The new CAP, which was implemented in 1992, gave rise to a major reduction in the number of farms throughout Europe, highlighting the dual character of the EU agricultural sector: highly subsidised family farms vs. highly productive and less subsidised corporate farms. In the Spanish case, this orientation would have 
underpinned the debate between family agriculture and corporate agriculture, favouring the latter which, in the mid 1990s represented a quarter of Spain's farms, but three quarters of its production (Lamo de Espinosa 1997, 184-5).

\section{CONCLUSIONS}

A review of the trajectory of the Spanish agricultural transformation after 1950 reveals that it shared the principal characteristics of the trend in Western Europe. This is not surprising given that Spain also shared the principal features of transformation processes with other countries: urban development, industrialisation and economic tertiarisation, increased imports of technology, dietary change... However, there were at least two important differences with respect to other Western European countries, with the exception of Portugal. First, the whole process took place within a dictatorial context in which the institutions and social groups that traditionally influenced and guided the political decisions were unable to exercise their role. Clearly responding to the approach adopted during the republican period, the agricultural policy was executed exclusively from the top in order to avoid the traditional class conflicts (between land owners and farm labourers). Second, and also related to this aspect, until 1986, Spain did not form part of any European regional trade agreement, not even the EFTA as in the case of Portugal. These two differences make Spain a unique case within the western agricultural transformation pattern.

The distinctive features of the Spanish case all respond to the same rationale: agricultural productivism at any cost. Whether it was the radical transformation of Spain's livestock farming or irrigation and with it the structure of crop production, in all cases there was an emphasis on an agriculture focused on intensive production, breaking 
away from the traditional agrarian model. This productive inertia gave rise to an agriculture based on economically large capitalised farms reinforced by the policies of the Franco regime. These policies and their effects did not suffer from the typical wearing down experienced by the democracies, as any opposition to them or proposed moderation was very weak or did not exist. While productivism was a characteristic shared by many countries at this time, Spain's principal distinguishing feature was that its productivism had no barriers or compensations. In contrast to the rest of the farmers in Western Europe, farmers in Spain received very little government support and their income was the lowest in Europe compared to the incomes of other economic activities. Furthermore, the rapid growth in Spanish agricultural production was based on two main elements that were hugely important: the increase in irrigation as an essential element for the expansion of crop production; and the rapid development of intensive livestock farming, explaining the fast growth in animal production.

After the arrival of democracy, initially few modifications were introduced and the model of agrarian change continued beyond Franco's dictatorship. However, Spain's accession to the EU implied a significant change in agricultural policies and gave it comfortable access to the European market, which stimulated significant growth in production, while that of the other Western European countries stagnated. On the other hand, the democratic change also gave rise to more complex decision-making processes, in which the different economic agents and social groups were able to intervene. The case of the hydraulic policy and the intense political and social debate surrounding it is a good example.

\section{REFERENCES}

Ackrill, R., 2000. The Common Agricultural Policy. Sheffield: Sheffield Acadmic Press. 
Agreste, 2010. A handbook of Agricultural Statistics, Ministére de l'Agriculture de l'Agroalimentaire et de la Forêt.

Anderson, K. and E. Valenzuela, 2008. Estimates of Global Distortions to Agricultural Incentives, 1955 to 2007. Washington D.C.: World Bank. http://www.worldbank.org/agdistortions [accessed 27/09/2015]

Arnalte, E.V., 2002. 'Ajuste estructural y cambios en los modelos productivos de la agricultura española'. In Agricultura y sociedad en el cambio de siglo, eds. J.J. González Rodríguez and C. Gómez Benito, 391-426. Madrid: McGraw-Hill, D.L.

Bairoch, P., 1999. L'agriculture des pays développés: 1800 à nos jours. Paris: Economica, cop. 1999.

Barceló, L.V., 1994. 'Políticas de modernización de la agricultura española'. In Modernización y cambio estructural en la agricultura española, ed. J.M. Sumpsi, 171242. Madrid: Ministerio de Agricultura, Pesca y Alimentación.

Barciela, C., I. López-Ortiz, J. Melgarejo and J.A. Miranda, 2001. La España de Franco (1939-1975). Madrid: Economía, Síntesis.

Bernal, A., 1993. 'Resignación de los campesinos andaluces: la resistencia pasiva durante el franquismo'. In España franquista. Causa general y actitudes sociales ante la dictadura, eds. I. Sánchez, M. Ortiz and D. Ruiz, 145-60. Cuenca: Universidad Castilla-La Mancha.

Brassley, P., Y. Segers and L. Van Molle (eds.), 2012. War, Agriculture, and Food. Rural Europe from the 1930s to the 1950s. London: Routledge.

Cabana, A. and Díaz-Gaeda, A., 2014. 'Exploring modernization: agrarian fascism in rural Spain, 1936-1951'. In Agriculture in the Age of Fascism, eds. L. Fernández-Prieto, J. Pan-Montojo and M. Cabo, 189-218. Turnhout: Brepols.

Carpintero, O. and J.M. Naredo, 2006. 'Sobre la evolución de los balances energéticos de la agricultura española, 1950-2000'. Historia Agraria, December, 40: 531-54.

Cazcarro, I., R. Duarte, M. Martín-Retortillo, V. Pinilla and A. Serrano, 2015a. 'How sustainable is the increase in the water footprint of the Spanish agricultural sector? A provincial analysis between 1955 and 2005-2010'. Sustainability, 7 (5): 5094-119. 
Cazcarro, I., R. Duarte, M. Martín-Retortillo, V. Pinilla and A. Serrano, 2015b. 'Water scarcity and agricultural growth in Spain: from curse to blessing?'. In Natural Resources and Economic Growth: Learning from History, eds. M. Badía-Miro, V. Pinilla, and H. Wilebald, 339-61. London: Routledge.

Christiansen, T., 2005. 'Crime and Punishment in the Black Market in Spain, 1940 - 53: An Analysis of the Fiscalía de Tasas'. Ager, Revista de Estudios sobre Despoblación y Desarrollo Rural / Journal of depopulation and rural development studies, 4: 63-99.

Christiansen, T., 2012. The reason why: the post civil-war agrarian crisis in Spain. Monografías de Historia rural, 9. Zaragoza: Prensas Universitarias de Zaragoza.

Clar, E., 2008. 'Farm policy under the Salazar and Franco dictatorships in Portugal and Spain: towards an authoritarian model of intervention in agriculture?'. In The state and rural societies. Policy and education in Europe, 1750-2000, ed. N. Vivier, 177-94. Turnhout: Brepols.

Clar, E., 2010. 'A world of entrepreneurs: the establishment of agribusiness during the Spanish pork and poultry boom, 1950-2000'. Agricultural History, 84 (2): 176-94.

Clar, E., 2013. 'Was Spain different? Agricultural change in Spain in a Southern European perspective, 1961 to 1985'. Agricultural History Review, 61 (2): 330-71.

Clar, E., M. Martín-Retortillo and V. Pinilla, 2016. 'Agricultura y desarrollo económico en España, 1800-2000'. In Estudios sobre el desarrollo económico español, eds. D. Gallego, L. Germán, and V. Pinilla. Zaragoza: Prensas Universitarias de Zaragoza.

Clar, E. and V. Pinilla, 2009. 'The contribution of agriculture to Spanish economic development, 1870-1973'. In Agriculture and economic development in Europe since 1870, eds. P. Lains and V. Pinilla, 311-32. London: Routledge.

Clar, E. and V. Pinilla, 2011. 'The modernization of agriculture under tough environmental constraints: one hundred years of Aragonese agricultural production, 1885-1985'. In Growth and Stagnation in European Historical Agriculture, eds. M. Olson and P. Svensson, 195-228. Turnhout: Brepols.

Clar, E., R. Serrano and V. Pinilla, 2015. 'El comercio agroalimentario español en la segunda globalización, 1951-2011’. Historia Agraria, 65: 149-86.

Collantes, F. and V. Pinilla, 2011. Peaceful Surrender: The Depopulation of Rural Spain in the Twentieth Century. Newcastle: Cambridge Scholars Publishing. 
Corominas, J., 2001. 'La infraestructura hidráulica de regadío en Almería'. In El sector agrario y agroalimentario de Almería ante el siglo XXI: evolución y perspectiva de nuestra agricultura en el año 2000, coord.. J.A. Salinas, Almería, pp. 13-31.

Corral, P., 2014. ¿Una sociedad ambiental? Historia de los conflictos ambientales bajo la dictadura franquista en Aragón (1939-1979). Unpublished Ph. D. dissertation, École des Hautes Études en Sciences Sociales, Paris.

Davis, J.H., 1955. 'Business responsibility and the market for farm products'. Address before Boston Conference on Distribution, John H. Davis papers.

Dovring, F., 1965. Land and labour in Europe in the 20th century: a comparative survey of recent agrarian history. The Hague: Martinus Nijhoff.

Duarte, R., V. Pinilla and A. Serrano, 2014. 'The water footprint of the Spanish agricultural sector: 1860-2010'. Ecological Economics, 108: 200-7.

Duarte, R., V. Pinilla and A. Serrano, 2016. 'Globalisation and Natural Recources: The Expansion of the Spanish Agrifood Trade and its Impact on Water Consumption, 19652010'. Regional Environmental Change, 16, 1: 259-272.

Esteban, E. and J. Albiac, 2012a. 'The problem of sustainable groundwater management: the case of La Mancha aquifers, Spain'. Hydrogeology Journal, 20(5): 851-863.

Esteban, E. and J. Albiac, 2012b. 'Assessment of Nonpoint Pollution Instruments: The Case of Spanish Agriculture'. International Journal of Water Resource Development, 28(1): 73-88.

EUROSTAT, 2013. EUROSTAT database. http://ec.europa.eu/eurostat [accessed May 2013].

Extezarreta, M., 2006. 'Algunos aspectos de la producción agropecuaria en España al principio del siglo XXI'. In La agricultura española en la era de la globalización, ed. M. Extezarreta, 253-309. Madrid: Ministerio de Agricultura, Pesca y Alimentación.

Evans, N., 2001. 'Reflexiones en torno al modelo productivista de la agricultura y la ganadería'. In El mundo rural en la era de la globalización: incertidumbre y potencialidades, ed. F. García Pascual, 45-64. Lleida: Universitat de Lleida; Madrid: Ministerio de Agricultura, Pesca y Alimentación. 
FAO, 1948-2004. FAO production yearbook. Rome, FAO.

FAOSTAT, 2009. FAO database. http://faostat.fao.org/site/291/default.aspx [accessed June 2009, April 2010 and October 2011].

Fearne, A., 1997. 'The history and development of the CAP, 1945-1990'. In The Common Agricultural Policy, eds. C. Ritson and D. Harvey, 11-56. Wallingford: Cabi Publishing.

Federico, G., 2005. Feeding the world: an economic history of agriculture, 1800-2000. Princeton: Princeton University Press.

Federico, G., 2012. 'Natura Non Fecit Saltus: The 1930s as the Discontinuity in the History of European Agriculture'. In War, Agriculture, and Food. Rural Europe from the 1930s to the 1950s, eds. P. Brassley, Y. Segers and L. Van Molle, 15-32. London: Routledge.

Fennell, R., 1997. The Common Agricultural Policy: Continuity and Change. Oxford: Clarendon Press.

Fernández García, E., 2008. 'Las políticas redistributivas de la España no democrática: del objetivo industrializador al sostenimiento de los ingresos de los agricultores (19501975)'. Investigaciones de Historia Económica, 12: 11-42.

Fernández, E., 2016. 'Politics, coalitions, and support of farmers, 1920-1975'. European Review of Economic History, 20 (1): 102-122.

Fernández-Prieto, L., J. Pan-Montojo and M. Cabo, 2014. Agriculture in the Age of Fascism. Turnhout: Brepols.

García-Grande, M.J., 2005. 'El último decenio: aplicación y consecuencias de la reforma de la PAC'. In Política agraria común: balance y perspectivas, eds. J.L. García-Delgado and M.J. García-Grande, 44-70. Barcelona, La Caixa.

Genovés, J.C., 1994. 'Modernización de la agricultura'. Papeles de Economía Española, 60-61: 174-82.

Gómez Benito, C. (1995): Políticos, burócratas y expertos. Un estudio de la política agraria y la sociología rural en España (1936-1959), Madrid, Siglo XXI. 
Gómez Benito, C. and E. Luque, 2007. 'Modernización agraria, modernización administrativa y franquismo. El modelo educativo y administrativo del Servicio de Extensión Agraria (1955-1986)’. Areas, 26: 131-49.

González, A., V. Pinilla and R. Serrano, 2016. 'International agricultural markets after the war, 1956-1960'. In Agriculture in Capitalist Europe, 1945-1960: From food shortages to food surpluses, eds. C. Martiin, J. Pan-Montojo and P. Brassley, 64-84. Abingdon: Routledge.

Gracia Royo, A. and L.M. Albisu, 2004. 'Evolución de la industria agroalimentaria española en las dos últimas décadas'. Economía Industrial, 355-6: 197-210.

Grigg, D.B., 1992. The transformation of agriculture in the West. New perspectives on the past. Oxford and Cambridge, USA: Blackwell.

Guzmán, G.I. and M. González de Molina, 2006. 'Sobre las posibilidades del crecimiento agrario en los siglos XVIII, XIX Y XX. Un estudio de caso desde la perspectiva energética'. Historia Agraria , 40: 437-70.

Hamilton, S., 2014. 'Agribusiness, the family farm, and the politics of technological determinism in the post-World War II United States'. Technology \& Culture, 55 (3): 560-90.

Herranz, A., 1995. 'La construcción de pantanos y su impacto sobre la economía y población del Pirineo aragonés'. In Pueblos abandonados. ¿Un mundo perdido?, eds. J.L. Acín and V. Pinilla, 79-102.

Ibarra, P., J. de la Riva, I. Iriarte, V. Rodrigo and I. Rabanaque, 2008. 'Impactos y efectos de la gestión y los usos del agua en la cuenca del Ebro'. In Gestión y usos del agua en la cuenca del Ebro en el siglo XX, ed. V. Pinilla, 607-656. Zaragoza: Prensas Universitarias de Zaragoza.

IFA, 2014. International Fertilizer Industry Association database. http://ifadata.fertilizer.org/ucSearch.aspx [accessed October 2014].

Josling, T., 2009. 'Western Europe'. In Distorsions to agricultural incentives: a global perspective, 1955-2007, ed. K. Anderson: 115-76. Washington: World Bank and Palgrave Macmillan.

Lamo de Espinosa, J., 1997. La década pérdida. 1986-1996: la agricultura española en Europa. Madrid: Ediciones Mundi-Prensa. 
Lanero, D. and A. Cabana, 2014. 'Equilibrios precarios, una microhistoria del poder local en acción bajo el franquismo'. In Otras miradas sobre golpe, guerra y dictadura. Historias para un pasado incómodo, eds. L. Fernández Prieto and A. Artiaga, 220-50. Madrid: Los Libros de la Catarata.

Lanero, D. and D. Freire, 2011. 'Introducción'. In Agriculturas e innovación tecnológica en la península ibérica (1946-1975), eds. D. Lanero and D. Freire, 9-24. Madrid: Ministerio de Medio Ambiente y Medio Rural y Marino.

Libecap, G.D., 1998. 'The Great Depression and the Regulating State: Federal Government Regulation of Agriculture'. In The Defining Moment. The Great Depression and the American Economy in the Twentieth Century, eds. M.D. Bordo, C. Goldin and E.N. White, 181-226. Chicago: The University of Chicago Press.

Martiin, C., J. Pan-Montojo and P. Brassley, 2016. Agriculture in Capitalist Europe, 1945-1960: From food shortages to food surpluses. Abingdon: Routledge.

Milward, A.S., 1984. The Reconstruction of Western Europe, 1945-51. London: Methuen.

Naredo, J.M. and J.M. Gascó, 1992. Las cuentas del agua en España. Madrid: Ministerio de Obras Públicas y Transporte.

Malassis, L., 1997. Les trois ages de l'alimentaire. Essai su une historie sociale de l'alimentation et de l'agriculture. Paris: Éditions Cujas.

Martín-Retortillo, M. and V. Pinilla, 2015a. 'Patterns and causes of growth of European agricultural production, 1950-2005'. Agricultural History Review, 63: 132-59.

Martín-Retortillo, M. and V. Pinilla, 2015b. 'On the causes of economic growth in Europe: why did agricultural labour productivity not converge between 1950 and 2005?'. Cliometrica, 9 (3): 359-96.

Martín-Retortillo, M., 2016. Transformaciones agrarias desde la historia económica cuantitativa: una visión de la producción y productividad agraria europea, 1950-2005. Paper presented in XIII Congreso de Historia Contemporánea, Albacete.

Ministerio de Agricultura, 1971. Informe sobre política de rentas y precios agrarios. Madrid: Ministerio de Agricultura. 
Moyano, E., 1994. 'Acción colectiva y cambio social en la agricultura española'. Papeles de Economía Española, 60-61: 234-42.

Naredo, J.M., 1996. La evolución de la agricultura en España. Desarrollo capitalista y crisis de las formas de producción tradicionales. Granada: Universidad de Granada.

Neal, L., 2007. The Economics of Europe and the European Union. Cambridge: Cambridge University Press.

Olmstead, A.L. and P.W. Rhode, 2008. Creating Abundance: Biological Innovation and American Agricultural Development. Cambridge and New York: Cambridge University Press.

Paniagua, A., 2016. 'Visiones en off de la despoblación rural en el franquismo', Ager. Journal of Depopulation and Rural Development Studies, 20: 139-160.

Pinilla, V., 2008. Gestión y usos del agua en la cuenca del Ebro en el siglo XX. Zaragoza: Prensas Universitarias de Zaragoza.

Pinilla, V. and R. Serrano, 2009. 'Agricultural and Food Trade in the European Union since 1963'. In Fertile Ground por Europe? The History of European Integration and the Common Agricultural Policy since 1945, ed. K. Patel, 273-300. Baden-Baden: Nomos.

Reis, J., 2000. 'How poor was the European periphery before 1850? The Mediterranean vs Scandinavia'. In The Mediterranean Response to Globalization Before 1950, S. Pamuk and J.G. Williamson, 17-44. Londres: Routledge.

Ríos, S. and D. Coq, 2014. 'The Transformation of the Spanish Livestock System in the Second and Third Food Regimes'. Journal of Agrarian Change, 15 (4): 519-40.

Ruiz-Maya, L., 1994. 'Distribución geográfica de las orientaciones técnico económicas e intensidad de la especialización de las explotaciones agrarias'. Papeles de Economía Española, 60-61: 38-49.

Sánchez-Chóliz, J. and R. Duarte, 2003. 'Analysing pollution by way of vertically integrated coefficients, with an application to the water sector in Aragon'. Cambridge Journal of Economics, 27: 433-48.

Sánchez de Puerta, F., 1996. Extensión agraria y desarrollo rural. Madrid: Ministerio de Agricultura, Pesca y Alimentación. 
Serrano, R., N. García-Casarejos, S. Gil-Pareja, R. Llorca-Vivero and V. Pinilla, 2015. 'The internationalisation of the Spanish food industry: the home market effect and European market integration'. Spanish Journal of Agricultural Research, 13 (3): 1-13.

Serrano, R. and V. Pinilla, 2011. 'Agricultural and food trade in European Union countries, 1963-2000: a gravity equation approach'. Économies et Sociétés, Série Histoire économique quantitative, $A F, 43$ (1): 191-219.

Sheingate, A.D., 2001. The rise of the Agriculture Welfare State. Institutions and interest group power in the US, France and Japan. Princeton and Oxford, Princeton University Press.

Silvestre, J. and J.E. Serrano, 2012. 'La representación en el cine de la integración de los inmigrantes rurales en las ciudades: el pesimismo de Surcos (1951)'. Ager: Revista de estudios sobre despoblación y desarrollo rural / Journal of depopulation and rural development studies, 12: 91-116.

Spoerer, M., 2015. 'Agricultural protection and support in the European Economic Community, 1962-92: rent-seeking or welfare policy?'. European Review of Economic History, 19 (2): 195-214.

Tello, E., 2010. 'Un vínculo perdido: energía y uso del territorio en la transformación histórica de los paisajes agrarios mediterráneos'. In Sombras del progreso: las huellas de la historia agraria, ed. R. Robledo, 353-66. Barcelona, Editorial Crítica. 